\title{
Kaj vpliva na učiteljevo izbiro učbenika?
}

\section{Milena Ivanuš Grmek, Monika Mithans, Polona Jančič Hegediš}

\section{Uvod}

Učbenik je posebna zvrst strokovne literature, ki jo določata vsebina in ciljna publika. Definicija učbenika je odvisna od šolskega sistema, saj vsebino $v$ najširšem smislu določa država $\mathrm{z}$ učnimi načrti, ki zajemajo vsebinske in operativne cilje predmeta oz. predmetnega področja (Turk Škraba, 20o6). Učbenik je učna knjiga, v kateri je znanost oz. stroka preoblikovana tako, da je dostopna vsem učencem, ki učbenik uporabljajo (Ivanuš Grmek, 2003). V 2. členu Pravilnika o potrjevanju učbenikov (2015) je učbenik opredeljen kot osnovno učno gradivo za doseganje vzgojno-izobraževalnih ciljev in standardov znanja, opredeljenih v učnem načrtu oz. katalogu znanja. Iz tega lahko razumemo, da lahko imajo učbeniki velik vpliv na uresničevanje ciljev učnega načrta (Hadar, 2017). Uporaba učbenika je vezana na določen šolski predmet in stopnjo izobraževanja (Pravilnik o potrjevanju učbenikov, 2. člen, 2015). Tako lahko učbeniku, kot temeljni šolski knjigi, ki jo učenci uporabljajo vsak dan (Ivanuš Grmek, 2003; Mullis, Martin, Foy \& Arora, 2012), pripišemo odločilno vlogo pri poučevanju šolskih predmetov (Skela, 2008).

Učbenik, eno izmed temeljnih učnih sredstev (Kovač idr., 2005), je namenjen uporabi tako učencem kot učiteljem (Remillard, 2005). Lahko je v funkciji učiteljevega poučevanja ali v funkciji učenja oz. učenčeve učne aktivnosti (Štefanc, 2005). Tudi v skladu z 2. členom Pravilnika o potrjevanju 
učbenikov mora učbenik $\mathrm{z}$ didaktično-metodično organizacijo vsebin in prirejeno likovno ter grafično opremo podpirati poučevanje in učenje. Njegova vsebina in struktura morata omogočati samostojno učenje in pridobivanje različnih ravni ter vrst znanja (Pravilnik o potrjevanju učbenikov, 2. člen). Učbeniki učencem predstavljajo učni vir za samostojno učenje in poglabljanje šolske razlage (Kovač idr., 2005) in učni vir, s pomočjo katerega naj bi se pri njih vzbudil interes za učenje (Hung Lau idr., 2018). Jurman (1999) učbeniku v procesu pouka pripisuje tako didaktično kot vzgojno funkcijo, saj posreduje znanja in omogoča razvijanje spretnosti, vrednosti in sposobnosti (Kukanja Gabrijelčič, 2015).

Učno-ciljna naravnanost učnih načrtov, ki je prinesla veliko avtonomije učiteljem, je tudi piscem in založnikom učbenikov omogočila različne vsebinske in pedagoške pristope ter pripomogla $k$ pluralizaciji ponudbe učbenikov (Kovač idr., 2005). Vsebino učbenikov opredeljujejo učni načrti, organizacija in podoba vsebin pa sta oblikovani na osnovi dosedanjih spoznanj didaktike (Filipčič, 2003). Filipčič (2003) opozarja na zmotno prepričanje o tem, da potrebuje učitelj en učbenik in en učni načrt. Takšno prepričanje zanemarja načelo avtonomije in načelo uvajanja raznolikih metod dela. Po njegovem mnenju je namreč pomembno upoštevati možnost prilagajanja načina dela in izbire primernih učnih gradiv ter se zavedati, da je izbira učbenika učiteljeva avtonomna odločitev, ki predstavlja zaupanje $\mathrm{v}$ njegovo strokovnost (Filipčič, 2003).

Pri izbiri učbenika lahko imajo učitelji (šole) popolno avtonomijo ali pa jih pri izbiri omejuje seznam potrjenih učbenikov (Kovač idr., 2005), kar velja tudi za slovenski šolski sistem. Pristojni strokovni svet potrdi učbenik, ki je v skladu s cilji vzgoje in izobraževanja ter s cilji, standardi znanja in vsebinami veljavnega učnega načrta oz. kataloga znanja. Poleg tega mora biti skladen s sodobnimi spoznanji stroke, $\mathrm{z}$ metodično-didaktičnimi načeli, $\mathrm{z}$ razvojno stopnjo in starostjo udeležencev izobraževanja. Pomembno je tudi, da je učbenik jezikovno pravilen in ustrezen ter tehnično, estetsko in vizualno pravilno oblikovan (3. člen, Pravilnik o potrjevanju učbenikov, 2015). Večja izbira učbenikov učiteljem omogoča, da izberejo učbenik, ki najbolj odgovarja njim in njihovim učencem. Pri izbiri najustreznejšega učbenika morajo učitelji imeti dovolj časa in možnosti, da preizkusijo nove učbenike in izberejo tistega, ki je zanje najprimernejši (Turk Škraba, 2006). $\mathrm{Na}$ izbor učbenika pogosto vplivajo mnenja in nasveti drugih učiteljev, poznavanje avtorjev, predstavitve s strani založb, priročniki k učbeniku, učbeniški sklad idr. (Filipčič, 2003). 
V nadaljevanju prispevka predstavljamo del širše empirične raziskave, ki je bila izvedena v okviru projekta Za kakovost slovenskih učbenikov (KaUč).V delu, ki ga prikazujemo v nadaljevanju, nas je zanimalo, kateri dejavniki vplivajo na učiteljevo izbiro učbenika. Zanimalo nas je torej, kateri so tisti kriteriji, ki imajo pri učiteljih največji vpliv na izbiro učbenika.

\section{Metodologija}

Širša raziskava je potekala v okviru projekta Za kakovost slovenskih učbenikov (KaUč), katerega glavni namen je razvoj kazalnikov kakovosti učbenikov za praktično uporabnost $\mathrm{v}$ procesu potrjevanja in evalvacije. Izvedena je bila pregledna deskriptivna neeksperimentalna empirična raziskava.

Podatke smo zbirali s pomočjo anketnega vprašalnika, ki ga sestavljajo sklopi anketnih vprašanj in sklopi ocenjevalnih lestvic. Veljavnost vprašalnika smo zagotovili $\mathrm{z}$ upoštevanjem dosedanjih znanstvenih spoznanj in s pregledom učiteljev praktikov. Zanesljivost vprašalnika temelji na natančnih, specifičnih vprašanjih, jasnih navodilih za izpolnjevanje ter sondažni uporabi. Objektivnost vprašalnika je bila v stopnji izvedbe zagotovljena tako, da je anketiranje potekalo elektronsko (individualno, brez prisotnosti raziskovalca) ter s prevladujočo izbiro vprašanj zaprtega tipa, ki omogočajo objektivno razbiranje odgovorov.

$\mathrm{V}$ raziskovalnem vzorcu je sodelovalo 151 učiteljev, ki poučujejo na osnovnih in srednjih šolah, vključenih v projekt KaUč. Od tega je bilo 44 učiteljev razrednega pouka (95,5\% ženskega spola) s povprečno starostjo 43,8 let $(\mathrm{MIN}=26, \mathrm{MAX}=59, \mathrm{~s}=9,5)$ in povprečno delovno dobo 20,6 let $(\mathrm{MIN}=1, \mathrm{MAX}=38, \mathrm{~s}=10,7)$. Gre torej za vzorec učiteljev, ki je z vidika delovnih izkušenj precej heterogen. Večina ima sedmo stopnjo izobrazbe $(61,4 \%)$ in poučuje v prvem vzgojno-izobraževalnem obdobju (63,6 \%). Med njimi jih je največ iz goriške $(34,1 \%)$, zasavske $(27,3 \%)$ in jugovzhodne $(22,7 \%)$ regije.

Prav tako je v raziskovalnem vzorcu sodelovalo 41 učiteljev predmetnega pouka (90,2 \% ženskega spola) s povprečno starostjo 44,2 let (MIN $=27, \operatorname{MAX}=64, \mathrm{~s}=8,7)$ in povprečno delovno dobo 18,7 let $(\mathrm{MIN}=3$, MAX $=38, s=10,1)$. Gre za vzorec predmetnih učiteljev, ki je z vidika delovnih izkušenj precej heterogen. Največ jih ima sedmo stopnjo izobrazbe $(56,1 \%)$ in poučujejo hkrati $\mathrm{v}$ drugem in tretjem vzgojno-izobraževalnem obdobju (56,1 \%), zgolj v tretjem (39\%) ali zgolj v drugem (4,9\%). Med njimi jih je največ iz goriške $(36,6 \%)$ in zasavske $(26,8 \%)$ regije. 
$\mathrm{V}$ anketiranju je sodelovalo tudi 66 srednješolskih učiteljev (77,3\% ženskega spola) s povprečno starostjo 45,3 let $(\mathrm{MIN}=30, \mathrm{MAX}=65, \mathrm{~s}=$ $9,3)$ in povprečno delovno dobo 18,9 let $(\mathrm{MIN}=1, \mathrm{MAX}=39$, s = 9,6). Gre za vzorec srednješolskih učiteljev, ki je $z$ vidika delovnih izkušenj precej heterogen. Največ jih ima sedmo stopnjo izobrazbe (72,7 \%). Med njimi prevladujejo učitelji iz srednjega splošnega izobraževanja $(61,5 \%)$ ter srednjega tehniškega in strokovnega izobraževanja (21,5\%). Anketirani srednješolski učitelji so iz dveh regij, in sicer iz zasavske $(60,6 \%)$ in goriške $(39,4 \%)$.

Pri učiteljih razrednega pouka so bili v analizo vključeni učbeniki za slovenščino, matematiko, družbo, spoznavanje okolja in naravoslovje in tehniko. Pri učiteljih predmetnega pouka je analiza zajela učbenike za matematiko, naravoslovje, biologijo, kemijo, fiziko, geografijo, zgodovino, slovenščino, angleščino, nemščino, glasbeno in likovno umetnost, tehniko in tehnologijo ter gospodinjstvo. Med srednješolskimi učbeniki so bili v analizo zajeti učbeniki za slovenščino, angleščino, nemščino, italijanščino, matematiko, biologijo, kemijo, fiziko, informatiko, geografijo, psihologijo, sociologijo, filozofijo in likovno umetnost.

Zaradi manjšega vzorca sodelujočih v anketiranju smo pri analizi podatkov uporabili metode deskriptivne statistike (frekvenčne distribucije, osnovna deskriptivna statistika), saj pogoji za metode posploševanja (inferenčne statistike) niso bili izpolnjeni.

\section{Rezultati}

V tretjem sklopu anketnega vprašalnika za učitelje smo preverjali dejavnike, ki so vplivali na njihovo izbiro učbenika. Ponujenih je bilo devet dejavnikov (npr. cena učbenikov, ravnatelj ali strokovni aktiv šole, uporabnost priloženega priročnika za učitelje, učitelji drugih šol, videz in podoba učbenikov, založnik in/ali predstavitev na založnikovem seminarju itd.) in kategorija drugo, ki je učiteljem omogočala, da so navedli dejavnik, ki ga med ponujenimi odgovori niso našli.

Pri vsakem dejavniku so se učitelji opredelili, ali je navedeni dejavnik vplival na njihovo izbiro učbenika ali ne. Zbrane rezultate o tem, kaj pri učiteljih vpliva na izbor določenega učbenika, predstavljamo v tabeli 1. 
Tabela i: Strukturni odstotki (f\%) učiteljev razrednega pouka, predmetnega pouka in učiteljev v srednjih šolah glede na posamezen dejavnik izbora

\begin{tabular}{lccc}
\multicolumn{1}{c}{ Dejavniki } & $\begin{array}{c}\text { Učitelji } \\
\text { razrednega } \\
\text { pouka } \\
\text { f } \%\end{array}$ & $\begin{array}{c}\text { Učitelji } \\
\text { predmetnega } \\
\text { pouka } \\
\text { f } \%\end{array}$ & $\begin{array}{c}\text { Učitelji } \\
\text { v srednjih } \\
\text { šolah } \\
\text { f } \%\end{array}$ \\
\hline Cena učbenikov & $\begin{array}{l}47,7 \\
16,7\end{array}$ & 13,6 \\
\hline Ravnatelj ali strokovni aktiv šole & 54,5 & 28,6 & 39,4 \\
\hline $\begin{array}{l}\text { Uporabnost priloženega priročnika za uči- } \\
\text { telje }\end{array}$ & 50,0 & 42,9 & 40,9 \\
\hline Učitelji drugih šol & 9,1 & 11,9 & 9,1 \\
\hline Videz in podoba učbenikov & 47,7 & 47,6 & 42,4 \\
\hline $\begin{array}{l}\text { Založnik in/ali predstavitev na založniko- } \\
\text { vem seminarju }\end{array}$ & 40,9 & 23,8 & 13,6 \\
\hline Priporočila s študijskih srečanj & 15,9 & 28,6 & 24,2 \\
\hline Sodelavci & 86,4 & 42,9 & 53,0 \\
\hline $\begin{array}{l}\text { Vsebina učbenikov in njihova metodično-di- } \\
\text { daktična zasnova }\end{array}$ & 86,4 & 92,9 & 74,2 \\
\hline
\end{tabular}

Iz tabele 1 je razvidno, da največ učiteljev razrednega pouka uporablja učbenik, ki so ga izbrali pod vplivom sodelavcev $(86,4 \%)$ in zaradi vsebine učbenika ter njegove metodično-didaktične zasnove $(86,4 \%)$. Dobra polovica je učiteljev, katerih izbira je pod vplivom ravnatelja ali strokovnega aktiva (54,5\%). Sledijo tisti, ki jim je pomembna uporabnost predloženega priročnika (50 \%), cena $(47,7 \%)$ in zunanji videz učbenika (47,7 \%) ter predstavitev založnika (40,9 \%). Najmanj je učiteljev, ki pri izbiri sledijo priporočilom študijskih skupin (15,9\%) in učiteljem drugih šol (9,1\%).

Pri učiteljih predmetnega pouka lahko iz rezultatov razberemo, da je večina učiteljev izbrala učbenik zaradi njegove vsebine in njihove metodično-didaktične zasnove (92,9 \%). Vsi drugi dejavniki so manj pomembni. Slaba polovica učiteljev namreč navaja vpliv videza učbenika $(47,6 \%)$ in sodelavcev $(42,9 \%)$ ter uporabnosti priročnika $(42,9 \%)$. Sledi vpliv ravnatelja $(28,6 \%)$ in študijskih srečanj $(28,6 \%)$, za tem založnika $(23,8 \%)$, cena $(16,7$ $\%)$ in na zadnjem mestu vpliv učiteljev drugih šol (11,9\%).

Prav tako lahko iz rezultatov $v$ tabeli 1 razberemo, da je za večino srednješolskih učiteljev temeljni razlog za izbiro učbenika njegova vsebina in metodično-didaktična zasnova (74,2 \%). Sledi polovica učiteljev, ki po pomembnosti izpostavljajo pomen sodelavcev (53\%), videza in podobe učbenika $(42,4 \%)$, uporabnosti priročnika $(40,9 \%)$ in vpliv ravnatelja ter strokovnega aktiva šole $(39,4 \%)$. Manj je učiteljev, katerih izbor je pod vplivom priporočil študijskih skupin (24,2 \%), predstavitve založnika $(13,6 \%)$ in cene 
učbenika (13,6 \%). Na zadnjem mestu kriterijev izbire učbenikov je po mnenju srednješolskih učiteljev mnenje učiteljev drugih šol (9,1 \%).

\section{Sklep}

Rezultati so pokazali, da večina učiteljev razrednega pouka uporablja učbenik, ki so ga izbrali pod vplivom sodelavcev ali zaradi vsebine in metodično-didaktične zasnove. Učitelji razrednega pouka so med pomembne dejavnike uvrstili še vpliv ravnatelja ali strokovnega aktiva, uporabnost priloženega priročnika in ceno učbenika. Najmanj učiteljev razrednega pouka pa se pri izbiri učbenika ozira na morebitna priporočila učiteljev drugih osnovnih šol. Tudi učitelji predmetnega pouka učbenik pogosto izberejo zaradi njegove vsebine in metodično-didaktične zasnove. Ostali dejavniki so jim pri izboru učbenika manj pomembni, saj jih manj kot polovica navaja vpliv videza učbenika, vpliv sodelavcev ter uporabnost priloženega priročnika. Najredkeje pa učbenik izberejo zaradi vpliva učiteljev drugih šol.

Pričujoči rezultati so vzpodbudni, saj vodi prevelik vpliv okolice na izbiro učbenika $\mathrm{v}$ nezadovoljstvo in nezadostno prilagajanje učbenika učiteljevemu načinu poučevanja, kar prispeva k slabšemu uspehu in želji po drugem učnem gradivu (Filipčič, 2003).

Tako kot njihovi osnovnošolski kolegi so tudi srednješolski učitelji pri izbiri učbenika upoštevali predvsem njegovo vsebino in metodološko-didaktično zasnovo.

Na podlagi rezultatov lahko zaključimo, da anketirani učitelji na vseh stopnjah šolanja - razredna in predmetna stopnja osnovne šole ter srednja šola - izbirajo učbenike predvsem zaradi njihove vsebine in metodično-didaktične zasnove. Glede na to, da večina učiteljev učbenik opredeljuje kot najpomembnejši vir pri pouku in da učbeniki ne vplivajo samo na to, kaj in kako se učenci učijo, ampak tudi, kaj in kako poučujejo učitelji (Mahmood, 2011), je takšna izbira učiteljev pričakovana. Učbeniki lahko učencem pomagajo v dojemanju njihovih izkušenj. Če vsebujejo ustrezna vprašanja in naloge, lahko učbeniki učence še bolj motivirajo k razmišljanju (Mahmood, 2011; Saeed, 2009), z ustrezno didaktično oblikovanostjo pa učbenik učence tudi neposredno usmerja k različnim kognitivnim miselnim aktivnostim (Poljak, 1991).

Učbeniki se po mnenju Justina (2007) med seboj zelo razlikujejo po učinkovitosti in zato je Kovač s sodelavci (2005) prepričan, da se mora vsak učitelj spraševati o ustreznosti izbranega učbenika. Na osnovi zapisanega smo lahko zadovoljni s pridobljenimi rezultati, ki kažejo na to, da se učitelji 
zavedajo pomena ustrezno vsebinsko in didaktično oblikovanega učbenika.

Na koncu bi radi opozorili na dejstvo, da pridobljeni in predstavljeni rezultati niso reprezentativni, saj so bili k sodelovanju povabljeni le učitelji osnovnih in srednjih šol, ki sodelujejo v projektu KaUč. Kljub tej omejitvi pa nam lahko pričujoči rezultati služijo kot usmeritev za nadaljnje raziskovanje. Raziskavo bi bilo smiselno nadgraditi s povečanjem raziskovalnega vzorca na reprezentativnega za celotno območje Republike Slovenije.

\section{Literatura}

Filipčič, Vincenc. „Izbor učbenikov kot strokovni izziv.“ Vzgoja in izobraževanje 34, no. 4 (2003): 55-56.

Hadar, Linor L. „Opportunities to learn: Mathematics textbooks and students' achievements." Studies in Educational Evaluation 55 (2017): 153-166. Accessed December 4, 2020. https://www.sciencedirect.com/science/article/abs/pii/So191491X17300949

Hung Lau, Kwok, Lam, Tri, Hon Kam, Booi, Nkhoma, Mathews, Richards, Joan and Thomas, Susan. „The role of textbook learning resources in e-learning: A taxonomic study." Computers \& Education, 118 (2018): 10-24. Accessed December 4, 2020. https://www.sciencedirect.com/science/article/pii/So360131517302403

Ivanuš Grmek, Milena. „Učbeniški kompleti v prvem triletju devetletne osnovne šole." Sodobna pedagogika 54, no. 5 (2003): 74-89.

Justin, Janez. „Opazen razvoj: kako dobri so naši učbeniki.“ Šolski razgledi 58 , no. 9 (2007): 3.

Jurman, Benjamin. Kako narediti dober učbenik: na podlagi antropološke vzgoje. Ljubljana: Jutro, 1999.

Kovač, Miha, Kovač Šebart, Mojca, Krek, Janez, Štefanc, Damijan in Vidmar, Tadej. Učbeniki in družba znanja. Ljubljana: Center za študij edukacijskih strategij, Pedagoška fakulteta, Univerza v Ljubljani, 2005.

Kukanja-Gabrijelčič, Mojca. „Učbenik po meri učenca?: mednarodna primerjalna analiza vprašanj in nalog v učbenikih za zgodovino." Annales: anali za istrske in mediteranske študije = annali di Studi istriani e mediterranei $=$ annals for Istrian and Mediterranean studies, 25, no 2 (2015): 385-398. Accessed December 4, 2020. http://www.dlib.si/details/URN:NBN:SI:doc-MHBW4NAM

Mahmood, Khalid., Iqbal, Muhammad Zafar and Saeed, Muhammad. "Textbook Evaluation Through Quality Indicators: The Case of Pakistan.“ 
Bulletin of Education \& Research, 31, no 2 (2009), 1-27. Accessed December 4, 2020. http://pu.edu.pk/images/journal/ier/PDF-FILES/1-Textbook \%2oevaluation \%2oarticle \%20(improved).pdf

Mahmood, Khalid. „Conformity to quality characteristics of textbooks: The illusion of textbook evaluation in Pakistan." Journal of Research and Reflections in Education, 5, no. 2 (2011): 170-190. Accessed December 4, 2020. http://citeseerx.ist.psu.edu/viewdoc/download?doi=10.1.1.1069.6438\&rep=re p1\&type $=$ pdf

Mullis, Ina, V.S., Martin, Michale. O., Foy, Pierre and Arora, Alka. »Trends in Mathematics and Science Study (TIMSS): International results in mathematics.« Boston: TIMSS \& PIRLS International Study Center, 2012. Accessed December 4, 2020. https:/eric.ed.gov/?id=ED544554

Poljak, Vladimir. »Didaktika«. Zagreb: Školska knjiga, 1991.

Pravilnik o potrjevanju učbenikov. Uradni list RS, (34/2015, 27/2017) (2015).

Remillard, Janine T. „Examining key concepts in research on teachers' use of mathematics curricula." Review of Educational Research, 75, no 2 (2005), 211-246. Accessed December 4, 2020. https://journals.sagepub.com/doi/ pdf/10.3102/00346543075002211

Skela, Janez. „Vrednotenje učbenikov v angleškem jeziku z vidika kognitivne teorije učenja." In Učenje in poučevanje tujih jezikov na Slovenskem: pregled sodobne teorije in prakse, edited ba Jaez Skela, 154-178. Ljubljana: Tangram, 2008.

Štefanc, Damijan. „Učbenik z vidika didaktične teorije: značilnosti, funkcije, kakovost in problematika potrjevanja." Sodobna pedagogika, 56, no 4 (2005): 172-185.

Turk Škraba, Mira. „Učbenik kot prvina učnega procesa.“ Vzgoja in izobraževanje, 37, no 5 (2006): 31-34. 